\title{
Metal Accumulation Profile in Roadside Soils, Grass and Caesalpinia Plant Leaves: Bioindicators
}

\section{Rolli NM ${ }^{1 *}$, Karalatti $\mathbf{B I}^{1}$ and Gadi SB ${ }^{2}$}

${ }^{1} B L D E A$ Degree College, Jamkhandi, Karnataka, India

'2JSS College, Dharwad, Karnataka, India

\begin{abstract}
Heavy metals are important environmental pollutants and their toxicity in human, plants and animals have been received much more attention. A study was conducted to investigate the heavy metal pollution of roadside soil, grass and Caesalpinia species of Bagalkot city (India). The highest levels of metal concentration of $\mathrm{Pb}, \mathrm{Cu}, \mathrm{Cd}, \mathrm{Mn}, \mathrm{Zn}, \mathrm{Cr}$ and $\mathrm{Ni}$ were found in the samples from very traffic congestion. The soil samples at a depth $(0-20 \mathrm{~cm}) \mathrm{grass}$ leaves and Caesalpinia leaves were taken from different sampling sites viz; $\mathrm{S}_{1}, \mathrm{~S}_{2}, \mathrm{~S}_{3}, \mathrm{~S}_{4}$ and $\mathrm{S}_{5}$ on state high way with high traffic roads passing through Bagalkot (India) were determined by Atomic Absorption Spectrophotometer. Results showed that soil and both grass and Caesalpinia contained elevated levels of the metal. It was found that the primary source of the contamination occurs mainly by the vehicular exhausts. The increased circulation of the toxic metals in soils, grass and Caesalpinia may result in the inevitable build up of such xenobiotics in the food chain. The variation in heavy metal concentration is due to the changes in traffic density and anthropogenic activities. Thus, it is concluded that grass, Caesalpinia and soil samples were used as bioindicators of metal pollution in roadside.
\end{abstract}

Keywords: Bioindicators; Xenobiotics; Caesalpinia; Grass; Food chain

\section{Introduction}

Environmental pollution has increasing in tremendous rate after global industrialization that has negative impacts on human health and ecosystem services [1]. The contribution of cars and road transports to the global emission of atmospheric pollutants is regularly increasing [2]. The road transports also induce the contamination of nearer soils by a pollutant transfer via the atmospheric fallouts [3] or road runoff $[3,4]$. Bagalkot is one of the busiest city in Karnataka, emission from transport vehicles results in significant heavy metal accumulation in roadside soils of Bagalkot city.

Nowadays, the toxic effects of heavy metals are burning issues and been studied by many researchers [5,6]. Entrance of heavy metals may occur in human and animal food chain as a result of their uptake by edible plants grown in contaminated soil [7]. The toxic and hazardous effects of some heavy metals on human health are very significant and may cause many fatal diseases. Lead $(\mathrm{Pb})$ is one of the heavy metal that is responsible for anemia, neurological disorder, hyperactivity and changes in blood enzymes in human body [8]. Cadmium (Cd) and $\mathrm{Zn}$ are important toxic metals and longtime exposure of which may causes renal, pulmonary, hepatic, skeletal, reproductive and many other carcinogenic effects $[9,10]$.

It is widely recognized that the principal reasons of heavy metals $(\mathrm{Pb}, \mathrm{Cu}$ and $\mathrm{Cd})$ derived from traffic congestion, long-range transport and household heating [2]. The spreading of contaminants is influenced by meteorological parameters such as rainfall, wind and traffic intensity [7]. The same meteorological conditions affect the concentration of same contaminants in the roadside soil [2]. The traffic density determines the lead level in soil and vegetation [11-13].

Soil samples and vegetation is the most economic and reasonable ways for assessing heavy metal status in the atmosphere [1]. Acacia [14], grass [15], other plants [16], and other organisms such as fish [17] have also have been used for monitoring. In order to assess contamination by metals in the vicinity of a highway, several studies have been carried out dealing with the different 3.1 compartments: study of global deposits, roadside soil and vegetation [2]. Information on accumulation of heavy metal on roadside soil of this city due to highway traffic and vehicles is very limited [18]. But this could be the new threat for agriculture. Determination of heavy metal accumulation in roadside soil may be an index of the environmental pollution of Bagalkot city. Keeping this view in mind, the research was conducted to know the heavy metal accumulation of roadside soil, grass and Caesalpinia of Bagalkot city.

\section{Materials and Methods}

Bagalkot is the city of Northern region of Karnataka at latitude $16^{\circ} 04^{1} \mathrm{~N}$ to $16^{\circ} 21^{1} \mathrm{~N}$ and longitude $75^{\circ} 26^{1} \mathrm{E}$ to $76^{\circ} 02^{1} \mathrm{E}$. The city is suffered from high traffic density caused by vehicles. The grass, Caesalpinia and soil were collected during 2013, which were three meters away from the State Highway (Figure 1 and Table 1) passing through Navanagar. Grass and Caesalpinia samples were collected from each site at three random spots that were spaced approximately at one meter interval. The leaves were clipped with stainless steel scissors. All the samples of each site were then combined to give composite samples of about 300 to $500 \mathrm{gm}$.

The leaves of Grass (Cyndon dactylon) and Caesalpinia (Caesalpinia pulcherrima) samples were dried at $80^{\circ} \mathrm{C}$ for $48 \mathrm{hr}$ fine by powdered and sieved through $0.2 \mathrm{~mm}$ sieve. One gram sample was digested using Gerhardt digestion unit using mixed acid digestion method [19]. The digested material was diluted with double distilled water and filtered through Whattman paper 41 and made upto $100 \mathrm{ml}$.

Similarly, soil samples were dried, powdered and sieved through

*Corresponding author: Rolli NM, BLDEA Degree College, Jamkhandi, Karnataka, India, Tel: 09448896839; E-mail: drnmrolli@rediffmail.com

Received July 22, 2015; Accepted August 24, 2015; Published August 29, 2015

Citation: Rolli NM, Karalatti BI, Gadi SB (2015) Metal Accumulation Profile in Roadside Soils, Grass and Caesalpinia Plant Leaves: Bioindicators. J Environ Anal Toxicol 5: 319. doi:10.4172/2161-0525.1000319

Copyright: $\odot 2015$ Rolli NM, et al. This is an open-access article distributed under the terms of the Creative Commons Attribution License, which permits unrestricted use, distribution, and reproduction in any medium, provided the original author and source are credited. 


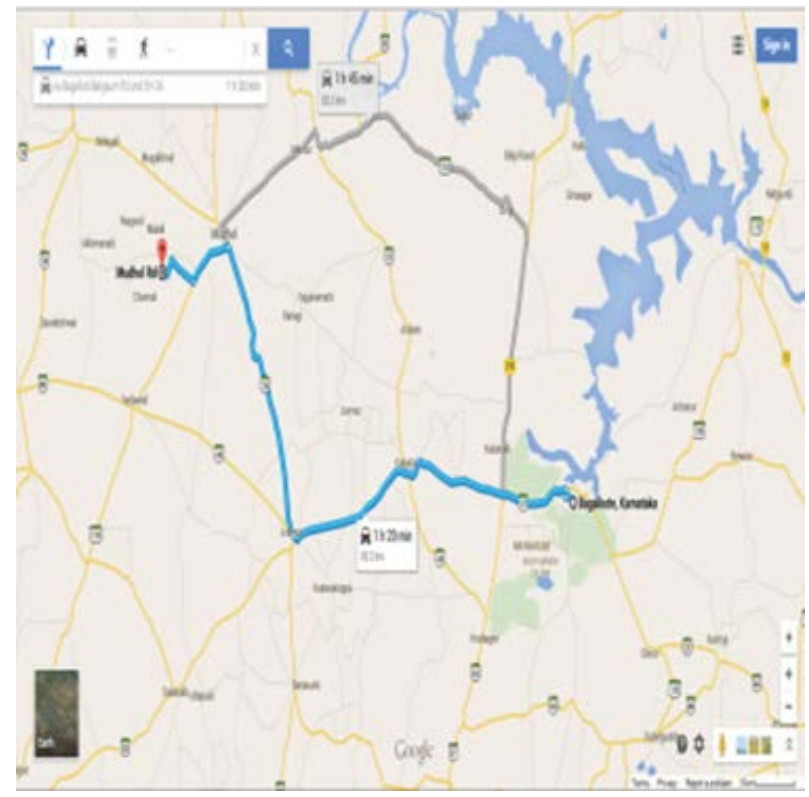

Figure 1: Map showing the State Highway of Bagalkot (Navanagar to Lokapur).

$0.2 \mathrm{~mm}$ sieve. One gm of sample was digested Gerhardt digestion unit according to Allen et al. method (mixed acid digestion method). The resulting extracts were diluted and filtered through Whattman No 41 paper and made upto $100 \mathrm{ml}$ using double distilled water and analyzed for heavy metals viz $\mathrm{Pb}$ (Lead), $\mathrm{Cd}$ (Cadmium), $\mathrm{Cu}$ (Copper), $\mathrm{Zn}$ (Zinc), Mn (Manganese), Ni (Nickel) and Cr (Chromium) with GBC932 plus Atomic Absorption Spectrophotometer (AAS) (Australia) with an air/acetylene flame and metal hollow cathode lamps. Respective wavelengths were used for the estimation of solutions for heavy metals were purchased from Siscochemical Laboratory Bombay $(1000 \mathrm{mg} / \mathrm{L})$ For Cd 228.8 nm, Pb 217.0 nm, Ni 232.0 nm, Cu 324.7 nm, Zn 213.9 $\mathrm{nm}, \mathrm{Mn} 279.5 \mathrm{~nm}$ and Cr $221.8 \mathrm{~nm}$ filters have been used for the estimation using AAS. The working standards were prepared by serial dilution of standard stock solutions and were used for the calibration of the instrument [19].

\section{Results and Discussion}

Pollution by heavy metals such as $\mathrm{Cd}, \mathrm{Pb}, \mathrm{Ni}, \mathrm{Cr}$ etc. is a pollution of concern [1]. So it has become necessary to conduct this study to exhibit and determine the kind of environmental pollution and how far they exhibit and efficient as the bioindicator in reducing the degree of pollution in environment. The level of heavy metals in the plants samples collected along the roadside Figure 1. Correlation coefficient of heavy metals in roadside soil, grass and Caesalpinia plant samples are given in the Tables 2 and 3 .

The ranges and arithmetic mean of heavy metal concentration of soil, grass and Caesalpinia samples of state high-way and control sites are presented in the Table 4 .

Lead is one of the major heavy metal and considered as an environmental pollutant [20]. Lead is considered as a general protoplasmic poison which is accumulate and slow acting. The main source of $\mathrm{Pb}$ is exhaust fumes of automobiles, chimneys of factory, roadside vehicles pollution [21]. The results of our analysis show that there are significant differences for lead between sampling sites in control and polluted area. The results shows that soil tends to accumulate more $\mathrm{Pb}$ than the grass and Caesalpinia leaves and the highest $\mathrm{Pb}$ level found in the roadside soil was $141.8 \mu \mathrm{g} / \mathrm{gm}$, while the Caesalpinia it was found that $29.39 \mu \mathrm{g} / \mathrm{gm}$. Similarly, in grass it was $29.39 \mu \mathrm{g} / \mathrm{gm}$. The mean soil $\mathrm{Pb}$ level of $95.71 \mu \mathrm{g} / \mathrm{gm}$ indicated considerable contamination of metal in the roadside environment, whereas, control soil has a baseline level of $70.50 \mu \mathrm{g} / \mathrm{gm} \mathrm{Pb}$ much of the lead is rapidly washed onto the soil by rain water from the surface and also by the death and decomposition of the plant. The $\mathrm{Pb}$ deposited in soils and vegetation can also cause enhanced levels of lead in soil microorganisms [22,23].

Road side soil gave higher ' $\mathrm{Cu}$ ' concentration due to industrial pollution near to the sampling location. The source of ' $\mathrm{Cu}$ ' being due to corrosion of metallic parts of cars derived from engine wear, brushing and bearing metals [24]. The mean $\mathrm{Cu}$ level in roadside soil $(49.71 \mu \mathrm{g} /$ gm) was found to be much higher than the grass $(4.87 \mu \mathrm{g} / \mathrm{gm})$ and Caesalpinia $(4.70 \mu \mathrm{g} / \mathrm{gm})$.

The source of $\mathrm{Zn}$ in relation to automobile traffic is: wearing of break lining, looses of oil and cooling liquid [25]. Arithmetic mean of $\mathrm{Zn}$ of the roadside soil of around Bagalkot shows a relatively high level of $188.31 \mu \mathrm{g} / \mathrm{gm}$ with a range of 32.29- 390.54 $\mu \mathrm{g} / \mathrm{gm}$. The range of $\mathrm{Zn}$ $24.40-35.70 \mu \mathrm{g} / \mathrm{gm}$ found in the Caesalpinia and grass $24.50-34.81 \mu \mathrm{g} /$ gm (roadside) is not much higher. This can be attributed to the fact that $\mathrm{Zn}$ as an essential element is normally present in uncontaminated plants up to $100 \mu \mathrm{g} / \mathrm{gm}[26]$

Cadmium is dispersed in natural environment through human activities as well as natural rock mineralization process thus plants can easily absorb Cd from soil and transport to the shoot system. Cadmium induces complex changes in plants genetically, biochemical and physiological levels. Our analysis for $\mathrm{Cd}$ in the roadside plants and soil showed that there significant differences between polluted and control area. Cadmium level in roadside soil averaged about $2.0 \mu \mathrm{g} / \mathrm{gm}$ and was the lowest among the seven metals examined. The mean Cd in Caesalpinia- $1.41 \mu \mathrm{g} / \mathrm{gm}$ and in grass $1.571 \mu \mathrm{g} / \mathrm{gm}$. The findings are in confirmation with the findings of [26].

The soil, grass and Caesalpinia contained much higher levels of Mn than other metals examined. Roadside soil, grass and Caesalpinia had average $1528.34 \mu \mathrm{g} / \mathrm{gm}, 56.606 \mu \mathrm{g} / \mathrm{gm}$ and $56.10 \mu \mathrm{g} / \mathrm{gm}$ of $\mathrm{Mn}$ respectively. High Mn content of the roadside soil may be attributed to the lithogenic factor apart from the vehicular pollution as indicated by the high values of $\mathrm{Mn}$ of control soil. Chromium is considered as a serious pollutant due to wide industrial use [27]. Chromium compounds are highly toxic to plants and are detrimental to their growth and development. Significant differences in our analysis for $\mathrm{Cr}$ in soil and in plant samples are found. Chromium level too was very high in roadside soil $(315.54 \mu \mathrm{g} / \mathrm{gm})$ against the control value of 118.41 $\mu \mathrm{g} / \mathrm{gm}$. In grass it was $4.90 \mu \mathrm{g} / \mathrm{gm}$ and in Caesalpinia it was found to be $4.61 \mu \mathrm{g} / \mathrm{gm}$ against the control (zero). Ni level was considerable and was in roadside soil $(85.91 \mu \mathrm{g} / \mathrm{gm})$ against control value $(69.38 \mu \mathrm{g} / \mathrm{gm})$. In grass it was $10.51 \mu \mathrm{g} / \mathrm{gm}$ and in Caesalpinia, it was found that $9.10 \mu \mathrm{g} /$ gm against control $(6.70 \mu \mathrm{g} / \mathrm{gm})$.

Simple linear regression between the metals $(\mathrm{Pb}, \mathrm{Cu}, \mathrm{Ni}, \mathrm{Mn}, \mathrm{Fe}$, $\mathrm{Zn}$ and $\mathrm{Cd}$ ) present in the soil, grass and Caesalpinia were calculated and are given in the Tables 3 and 4 .

According to simple linear regression between the metal levels in roadside soil and the Caesalpinia were found in $\mathrm{Zn}, \mathrm{Cd}$ and $\mathrm{Ni}$ are significant at $5 \%$ level $(p<0.05)$. It may be indicating the bioconcentration of these metals in the Caesalpinia, in addition to aerial deposition. This may be attributed to the favorable root environment 
Citation: Rolli NM, Karalatti BI, Gadi SB (2015) Metal Accumulation Profile in Roadside Soils, Grass and Caesalpinia Plant Leaves: Bioindicators. J Environ Anal Toxicol 5: 319. doi:10.4172/2161-0525.1000319

Page 3 of 4

\begin{tabular}{|c|c|c|}
\hline Station No. & Sampling station & Nature of stations \\
\hline Control & Navanagar (Bagalkot) & Unpolluted urban area- vehicular movement is negligible, unpolluted area with less disturbance \\
\hline $\mathbf{1}$ & Navanagar Bypass road & Vehicular movement is high \\
\hline $\mathbf{2}$ & Near Simikeri & Behicular movement is high. Agricultural fields on either side of the road \\
\hline $\mathbf{3}$ & Tulasigeri & Vehicular movement is high. Agricultural fields on either side of the road \\
\hline $\mathbf{4}$ & Kaladagi & Vehicular movement is high. Agricultural fields on either side of the road \\
\hline $\mathbf{6}$ & Lokapur & Vehicular movement is high. Agricultural fields on either side of the road \\
\hline
\end{tabular}

Table 1: Sampling stations along State Highway of Bagalkot.

\begin{tabular}{|c|c|c|}
\hline S. No. & Metal & $\boldsymbol{r}$ value \\
\hline $\mathbf{1}$ & Lead & $0.628^{*}$ \\
\hline $\mathbf{2}$ & Copper & $0.481^{*}$ \\
\hline $\mathbf{3}$ & Zinc & $0.829^{*}$ \\
\hline $\mathbf{4}$ & Cadmium & $0.748^{*}$ \\
\hline $\mathbf{5}$ & Manganese & $0.529^{*}$ \\
\hline $\mathbf{6}$ & Nickel & $0.331^{*}$ \\
\hline $\mathbf{7}$ & Chromium & $0.215^{*}$ \\
\hline
\end{tabular}

Table 2: Correlation coefficient of heavy metals in roadside soil and grass. Significant at $5 \%$ level $(p<0.05)$.

\begin{tabular}{|c|c|c|}
\hline S. No. & Metal & $\boldsymbol{r}$ value \\
\hline $\mathbf{1}$ & Lead & $0.627^{\star}$ \\
\hline $\mathbf{2}$ & Copper & $0.480^{\star}$ \\
\hline $\mathbf{3}$ & Zinc & $0.824^{\star}$ \\
\hline $\mathbf{4}$ & Cadmium & $0.740^{\star}$ \\
\hline $\mathbf{5}$ & Manganese & $0.520^{\star}$ \\
\hline $\mathbf{6}$ & Nickel & $0.321^{\star}$ \\
\hline $\mathbf{7}$ & Chromium & $0.210^{\star}$ \\
\hline
\end{tabular}

Table 3: Correlation coefficient of heavy metals in roadside soil and Caesalpinia. Significant at $5 \%$ level $(p<0.05)$.

\begin{tabular}{|c|c|c|c|c|c|c|c|c|c|}
\hline \multirow[t]{2}{*}{ S. No. } & \multirow[t]{2}{*}{ Heavy metals } & \multirow[t]{2}{*}{$\begin{array}{l}\text { Control Group } \\
\text { ( } \mu \mathrm{g} \mathrm{g}^{-1} \text { dry wt.) }\end{array}$} & \multicolumn{2}{|c|}{$\begin{array}{l}\text { Roadside Caesalpinia } \\
\text { ( } \mu \mathrm{g} \mathrm{g}^{-1} \text { dry wt.) }\end{array}$} & \multicolumn{2}{|c|}{ Roadside grass } & \multirow[t]{2}{*}{$\begin{array}{c}\text { Control } \\
\text { ( } \mu \mathrm{g} \mathrm{g}^{-1} \text { dry wt.) }\end{array}$} & \multicolumn{2}{|c|}{ Roadside soil ( $\mu \mathrm{g} \mathrm{g}^{-1}$ dry wt.) } \\
\hline & & & Range & Mean \pm SE & Range & Mean \pm SE & & Range & Mean \pm SE \\
\hline 1 & Lead & 18.46 & $20.36-29.39$ & $23.73 \pm 1.84$ & $20.46-29.39$ & $23.736 \pm 1.84$ & 70.50 & $82.91-141.8$ & $95.71 \pm 8.71$ \\
\hline 2 & Copper & 2.15 & $3.92-5.74$ & $4.70 \pm 0.35$ & $3.95-5.76$ & $4.87 \pm 0.35$ & 34.91 & $39.54-59.29$ & $49.71 \pm 3.51$ \\
\hline 3 & Zinc & 16.19 & $24.40-35.7$ & $32.84 \pm 3.10$ & $24.50-34.8$ & $32.87 \pm 3.11$ & 29.84 & $32.29-390.54$ & $188.3 \pm 54.28$ \\
\hline 4 & Cadmium & 0.82 & $1.10-1.79$ & $1.41 \pm 0.08$ & $1.20-1.82$ & $1.571 \pm 0.082$ & 2.16 & $1.75-2.91$ & $2.0 \pm 0.19$ \\
\hline 5 & Manganese & 15.72 & $28.01-70.10$ & $56.10 \pm 7.30$ & $28.91-72.24$ & $56.606 \pm 7.36$ & 1254.1 & $1257.9-2057.5$ & $1528.3 \pm 26.5$ \\
\hline 6 & Chromium & ND & $1.20-8.4$ & $4.61 \pm 2.20$ & $1.30-9.00$ & $4.90 \pm 2.23$ & 110.41 & $131.9-958.2$ & $315.54 \pm 2.46$ \\
\hline 7 & Nickel & 6.70 & $8.1-14.9$ & $9.10 \pm 1.40$ & $8.8-15.1$ & $10.51 \pm 1.411$ & 69.38 & $70.53-109.6$ & $85.91 \pm 5.91$ \\
\hline
\end{tabular}

Table 4: Heavy metal accumulation profile in Caesalpinia grass and soil. ND: Not detectable.

[28] i.e., soil conditions might have favored their absorption.

Simple linear regression in case of chromium, nickel, manganese and copper contents between soil, grass and Caesalpinia are not at significant at $5 \%$ level, were low due to low bioavailability of these metals owing to unfavorable root environment. Whatever excess content of these metals found in soil, grass and Caesalpinia was presumed to be due to the aerial deposition contributed by motor vehicles.

The order of increment of heavy metals in roadside soil is as follows: $\mathrm{Mn}>\mathrm{Cr}>\mathrm{Zn}>\mathrm{Pb}>\mathrm{Ni}>\mathrm{Cu}>\mathrm{Cd}$, whereas in grass: $\mathrm{Mn}>\mathrm{Zn}>\mathrm{Pb}>\mathrm{Ni}>\mathrm{Cr}>\mathrm{Cu}>\mathrm{Cd}$ and in Caesalpinia: $\mathrm{Mn}>\mathrm{Zn}>\mathrm{Pb}>\mathrm{Ni}>\mathrm{Cu}>\mathrm{Cr}>\mathrm{Cd}$ The elevated levels of heavy metals in the roadside soil and Caesalpinia is an indication of airborne pollutants of roadside environment of the urban area of Bagalakot city and along the road. Soils due to their cation exchange capacity (CEC), complexing organic substances, oxides and carbonates, have high retention capacity for the heavy metals [29]. Thus, contamination levels increase continuously as long as the nearby sources remain active. During the last decade, the city of Bagalakot has witnessed sharp increase in vehicle number due to urbanization. Similar observation in Caesalpinia in Madhurai city of southern region of Tamil Nadu [30].

In soil, the lesser mobility of metals and its accumulation on a long-term basis, leads to overall higher contamination level of metals; whereas, in roadside grass, Caesalpinia it represents more accumulation due to turnover of plant materials (like new growths, the senescence followed by abscission of old parts) and meteorological influences [31]. Thus, the study of metal concentration of roadside soil, grass and Caesalpinia reflects the extent of aerial contamination of the roadside environment. The penetration of heavy metals into the food chains due to vehicular emissions may cause a long- range ecological and health hazard.

The results of our study indicate that the concentration of heavy metals such as $\mathrm{Pb}, \mathrm{Cd}, \mathrm{Mn}, \mathrm{Zn}, \mathrm{Ni}, \mathrm{Cu}$ and $\mathrm{Cr}$ from the traffic area is an indicative of anthropogenic pollution. It was concluded that with an increase in the amount of heavy metals in soil and their uptake by plants also increase. The mobility of heavy metals showed that are 
Citation: Rolli NM, Karalatti BI, Gadi SB (2015) Metal Accumulation Profile in Roadside Soils, Grass and Caesalpinia Plant Leaves: Bioindicators. J Environ Anal Toxicol 5: 319. doi:10.4172/2161-0525.1000319

\section{References}

1. Onder S, Dursun S (2006) Air borne heavy metal pollution of Cedrus libani (A Rich.) in city center of Koyna (Turkey). Atmospheric Environment 40: 11221133.

2. Viard b, Pihan F, Promeyrat S, Pihan JC (2004) Integrated assessment of heavy metal highway pollution: Bioaccumulation in soil, Graminaceae and land snails. Chemosphere 55: 1349-1359.

3. Nabuloa G, Oryem-Origa H, Diamond M (2006) Assessment of lead, cadmium, and zinc contamination of roadside soils, surface films, and vegetables in Kampala City, Uganda. Environmental Research 101: 42-52.

4. Mitsch WJ, Gosselink JG (1993) Wetlands (2nd edn) Van Nostrand-Reinhold USA.

5. Yang XE, Long XX, Ni WZ, Ye ZQ, Fe ZL, et al. (2002) Assessing coppe thresholds for phytotoxicity and potential dietary toxicity in selected vegetable crops. J Environ Sci Health B 37: 625-635.

6. Nordberg G (2003) Cadmium and human health: A perspective based on recent studies in China. The Journal of Trace Elements in Experimental Medicine 16: 307-319.

7. Bakirdere S, Yaman M (2007) Determination of lead, cadmium and copper in roadside soil and plants in Elazig, Turkey. Environmental Monitoring Assessment 136: 401-410.

8. Mortula MM, Rehman MS (2002) Study on waste disposal at DEPZ. Bangladesh Environmental Protection Agency 2: 807-817.

9. Arora M, Kiran B, Rani A, Rani S, Kaur B, et al. (2008) Heavy metal accumulation in vegetables irrigated with water from different sources. Food Chemistry 111 811-815.

10. Bhuiyan MA, Suruvi NI, Dampare SB, Islam MA, Qurashi SB, et al. (2011) Investigation of the possible sources of heavy metal contamination in lagoon and canal water in the tannery industrial area in Dhaka, Bangladesh. Environ Monit Assess 175: 633-649.

11. Othman IM, Al-Oudat, Al-Masri MS (1997) Lead levels in roadside soils and vegetation of Damascus city. Sci Total Environment 207: 43-48.

12. Hjortenkrans D, Bergback $B$, Haggerud A (2006) New metal emission patterns in road traffic environments. Environ Monit Assess 117: 85-98.

13. Grigalaviciene I, Rutkoviene V, Marozas V (2005) The accumulation of heavy metals $\mathrm{Pb}, \mathrm{Cu}$ and $\mathrm{Cd}$ at roadside forest soil. Polish Journal of Environmental studies 14: 109-115.

14. Aksoy A, Ahin U, Duman F (2000) Robinia Pseudo-acacia L. as a possible biomonitor of heavy metal pollution in Kayseri. Tropical Journal of Botany 24 179-284.

15. Fatoki OS (2003) Lead, cadmium and zinc accumulation a long some selected major roads if Eastern cape. International Journal of Environmental studies 60 199-204.
16. Aksoy A, Celik A, Ozturk M (2000) Plants as possible indicators of heavy metal pollution in Turkey. Chemia Inzyneria Ekologiczna 11: 1152-1161.

17. Rashed NM (2001) Monitoring of environmental heavy metals in fish from Nasser Lake. Environment International 27: 27-33.

18. Aktaruzzaman M, Fakhruddin AN, Choudhary MA, Fardous Z, Alam MK (2013). Accumulation of heavy metals in soil and their transfer to leafy vegetables in the region of Dhaka Aricha Highways, Savar, Bangladesh. Pakistan Journal of Biological Science, 16: 332-338.

19. Allen SE, Grimshow HM, Parkinson JA, Quamby C (1974) Chemical analysis of ecological materials. Blackwell Scientific Publications. Osney Mead, Oxford UK.

20. Sharma P, Dubey RS (2005) Lead toxicity in plants. Brazilian Journal of Plant Physiology 17: 35-52.

21. Eick MJ, Peak JD, Brady PV, Pesek JD (1999) Kinetics of lead adsorption and desorption of Gooethite: residence time effect. Journal of Soil Science. 164 28-39.

22. Harrison RM, Laxen DPH, Wilson SJ (1981) Chemical association of lead cadmium, copper and zinc in street dust and roadside soils. Environ. Sci. Technol 15: 1378-83.

23. Khattak MI, Jana Akhatar, Rehan K (2013) Study of Pb concentration in roadside plants (Dalbergia sissoo and Cannabis sativa) in region of quetta. Sci Int 25: 347-352.

24. Al-Khashman OA (2007) The investigation of metal concentration in stress dust samples in Aqaba city, Jordan. Environ Geochem Health 29: 197-207.

25. Saeedi M, Hosseinzadeh M, Jamshidi A, Pajooheshfar SP (2009) Assessment of heavy metals contamination and leaching characteristics in highway side soils, Iran. Environmental Monitoring Assessmen 151: 231-241.

26. Ho YB, Tai KM (1988) Elevated levels of lead of lead and other metals in roadside soils and grasses and their use to monitor aerial metal-depositions in Hongkong. Env Pollu 49: 37-51.

27. Shanker AK, Cervantes C, Loza-Tavera H, Avudainayagam S (2005) Chromium toxicity in Plants. Environment International 31: 739-753.

28. Sahu KC, Warrier R (1985) Lead, cadmium and copper contamination of soil and vegetation due to vehicular emission along Powai road in North Bombay, India. Indian J Earth Science 12: 50-57.

29. Yassoglou N, Kosomas C, Asimakopoulos J, Kallianou C (1987) Heavy metal contamination of roadside soils in the Greater Athens area. Environmental Pollution 47: 293-304.

30. Thambavani SD, Vathana VM (2013) Caesalpinia as indicator for heavy metals pollution. Elixir Polllution. 57: 14335-1434.

31. Kabata-Pendias A, Pendias H (2001) Trace elements in soils and Plants, 3rd edn. CRC Press, Boca Raton. 